\title{
Students' perception toward the use of tiktok video in learning writing descriptive text at MAN 1 Gresik
}

\author{
Syaifuddin ${ }^{1}$, Wiwik Muyassaroh Abdi ${ }^{2}$, Alfufatin Nabilah ${ }^{3}$, Dewi Larassati M.P ${ }^{4}$, Fairuz \\ Lazuwardiyyah ${ }^{5}$ \\ 1,2,3,4,5Universitas Islam Negri Sunan Ampel Surabaya, MAN 1 Gresik \\ 1'syaifuddin_mr@yahoo.co.id, 2wiwikabdi@ymail.com, ${ }^{3}$ alfufatinbilla@gmail.com, \\ 4dewilarassat63@gmail.com,5fairuzzlazuwardiyyah@gmail.com \\ *) correspondence: alfufatinbilla@gmail.com
}

\begin{abstract}
The purpose of this study was to explain the students' perception towards the use of TikTok in learning writing descriptive text. This analysis was a descriptive quantitative with a survey approach through questionnaire. The total of sample was 85 students at Islamic Senior High School of 1 Gresik especially from X MIPA 3, X MIPA 4, and X MIPA 5 in the 2020/2021 academic year. The information of this study was obtained through 15 questions adapted from Ilmiyah et al. \& Ilmi. The researchers analyzed the data from questionnaire using SPSS 16 program to find out the descriptive statistical analysis. The finding captured that the interpretation of students regarding the use of TikTok in descriptive text of learning writing was positive. The students said they agreed with the use of TikTok in learning writing descriptive text due to it contributes positively and can foster the motivation of students. Furthermore, it makes the learners pay attention and participate in the learning process. Therefore, it is also recommended to students and teachers to use TikTok in order to create a contextual, relevant, and meaningful learning process, especially in writing descriptive text. They also allow students to participate in the learning process actively.
\end{abstract}

Keywords: TikTok; video; descriptive text

\section{INTRODUCTION}

Writing is one of the abilities in English that must be taught by the students. To acquire it, the students should get enough writing practices such procedures are intended to stimulate the abilities of the students in writing a good passage, without rehearse, it is impossible to write well and effectively. Writing is a productive skill that considered as the most difficult skill in learning language (Khoii, 2011).

Writing is widely considered to be the most important role in language learning as it is needed for academic purposes. It has been used as a strategy by teachers to improve conceptual learning and to help students organize their thoughts. As Hiew (2005) argues flowing ideas are required for students to write without difficulty. Often the teacher's interpretation of the material is difficult to understand for most students when teaching writing in English. To fill in the teacher void explanations and the capacity of students to understand, the presence of the media is very important.

Teaching aids are important tutoring instruments that can make learning possible more efficient and interesting. In teaching and learning process, teachers' obligation is to support their students by when using the selection of varieties, essential customers become sources in the media. Every student is surrounded by different media, such as books, magazines, internet, and many others. Harmer (2007) stated that there are several items, images, and other items that can be used to display as instructional media language manipulation and the involvement of students. In addition, Mayer (2012) stated as cited in Hadi et. al. (2020) that the media moving image-based learning (animation / video) can 
encourage learners understanding when it used in a manner consistent with multimedia learning theory. Multimedia is the use of devices to represent and present integrate text, audio, linked video and tooling tools that enabling users to browse, chat, create and create communication.

There are many various videos that can use in teaching and learning process, such as TikTok video. TikTok is a video sharing short app that enables users to build and share 60-second videos on any subject. ${ }^{1}$ According to Demmy and Fathul (2018) Tik Tok is the latest social media application that allows users to create interesting videos and interact with them in comments and private chats. This application presents interesting and easy to use special effects. So that everyone can create an impressive video, this is what makes Tik-Tok an application with many users.

Though it may come as a surprise for many of the readers, there are already TikTok Clubs in some schools in the USA, and teachers are using TikTok for student interaction. One of the reasons they strongly offer is that students already have a platform account, and it is easier to use the technology's tools to engage them in innovative learning using video. ${ }^{2}$ The TikTok platform allows users to create and upload video content, including music videos, and includes editing tools that allow near-professional results for anyone to make. In the education arena, maybe the most powerful use of TikTok is teacher-made videos that students can watch repeatedly.

Some teachers have developed their own clips to illustrate complicated concepts or share specific task instructions in the spirit of flipped classrooms. Students benefit from this process, since they do not have the distraction of trying to catch each word in their notes. Instead, they have unrestricted access to the most relevant points in the video version. Using TikTok in this way also removes possible problems that come with student use.

In this study, the researchers use TikTok video to teach writing, especially in writing a descriptive text. According to Gerot and Wignell (1994), "descriptive text is a text type we use when we want to tell how something looks, smells, feels, acts, tastes, sound etc". Essentially, it provides details about characteristics of people, places, and things. The details are used to help the reader in creating a mental image. Moreover, Abisamra (2001) has similar opinion about descriptive text. He adds that "descriptive is the text picturing the person, place and thing with clear detail to help the readers visualize an object which is described" So, by writing a descriptive text, the researcher will create their feel of impression and get a clear image of the object which is describe.

Furthermore, description activity is used to describe an object and the readers become easily to be understood, so that they can imagine the object which is described clearly like the real one. In addition, the construction of the text must be known before writing the descriptive text. The generic structure of descriptive text are identification and description. Introduction tells about the introduction of the object that will be described such as what, when, who, and what question. While, description tells about the specific information or features of the object, it can be characteristics, parts, qualities, size, and many others.

In this research, the research needs to be conducted in order to know how useful and intensive the use of TikTok in developing the students' writing skill especially in writing descriptive text. Therefore, this study will point out whether the use of TikTok gives any contribution in learning writing descriptive text or in the other way. The purpose of the research is to find out students' perceptions toward the use of TikTok video in learning writing descriptive text at MAN 1 Gresik.

\section{METHODS}

This research using descriptive quantitative as the method. This study was conducted at MAN 1 Gresik with the subjects were students of class X MIPA 3, X MIPA 4, and X MIPA 5 who were in the academic year 2020/2021. The total number of subjects was 85 participants. To collect the data of this study, the researcher used questionnaire. The questionnaire consisted of fifteen items. The items of questionnaire were classified into three categories such the following list: 
1. Question 1-5 deal with students' perception toward the use of TikTok in learning writing Descriptive Text

2. Question number 6-10 deal with the specific contribution of TikTok

3. Question number 11-15 deal with the criteria of using TikTok in teaching and learning activity

In this study, the researchers analyzed the data from questionnaire filled by participants by using SPSS 16 program to find out the descriptive statistical analysis. Descriptive statistics such as means, frequency, standard deviation, and percentage were used to find out the students' perception toward the use of Tiktok in learning writing descriptive text.

\section{RESULTS AND DISCUSSION}

To know the reliability of the test of learning writing Descriptive Text using TikTok, first it was tested out to 85 students. The following table presents the reliability statistics for the test. The value of Cronbach's Alpha was 969 which means that the test was reliable.

TABLE 1. Reliability Statistics

\begin{tabular}{ccc}
\hline Cronbach'S Alpha & $\begin{array}{c}\text { Cronbach's Alpha Based on } \\
\text { Standardized Items }\end{array}$ & N of Items \\
\hline .929 & .969 & 18 \\
\hline
\end{tabular}

The result of the questionnaire was converted into numerical values based on Hadiyanto \& Arif, (2012)'s analysis.

TABLE 2. Interpretation of mean score

\begin{tabular}{lcc}
\hline No. & Mean Score & Interpretation \\
\hline 1. & $1.00-1.80$ & Very low \\
\hline 2. & $1.81-2.60$ & Low \\
\hline 3. & $2.61-3.40$ & Medium \\
\hline 4. & $3.41-4.20$ & High \\
\hline 5. & $4.21-5.00$ & Very high \\
\hline
\end{tabular}

The table below is the questionnaire answered by the respondents with the frequency, percentage, mean, standard deviation, and level interpretation.

TABLE 3. Frequency, Percentage, Mean, Standard Deviation and Level Interpretation

\begin{tabular}{|c|c|c|c|c|c|c|c|c|c|}
\hline \multirow[t]{2}{*}{ No } & \multirow{2}{*}{$\begin{array}{l}\text { Perception toward the use of } \\
\text { Tik Tok in learning writing } \\
\text { Descriptive Text }\end{array}$} & \multicolumn{5}{|c|}{ Frequency \& percentage } & \multirow[t]{2}{*}{ Mean } & \multirow[t]{2}{*}{ S.td } & \multirow{2}{*}{$\begin{array}{l}\text { Level } \\
\text { Interpretation }\end{array}$} \\
\hline & & SA & $\mathbf{A}$ & QA & $\mathbf{D}$ & SD & & & \\
\hline 1 & $\begin{array}{l}\text { I am happy to learn Desciptive } \\
\text { Text by watching videos through } \\
\text { Tik Tok }\end{array}$ & $\begin{array}{l}25 \\
(29.4 \%)\end{array}$ & $\begin{array}{l}30 \\
(35.3 \%)\end{array}$ & $\begin{array}{l}23 \\
(27.1 \%)\end{array}$ & $\begin{array}{l}5 \\
(5.9 \%)\end{array}$ & $\begin{array}{l}2 \\
(2.4 \%)\end{array}$ & 3.84 & .998 & High \\
\hline 2 & $\begin{array}{l}\text { Tik Tok makes it easier for me to } \\
\text { imagine certain objects in } \\
\text { specific or in more detail }\end{array}$ & $\begin{array}{l}21 \\
(24.7 \%)\end{array}$ & $\begin{array}{l}34 \\
(40.0 \%)\end{array}$ & $\begin{array}{l}21 \\
(24.7 \%)\end{array}$ & $\begin{array}{l}7 \\
(8.2 \%)\end{array}$ & $\begin{array}{l}2 \\
(2.4 \%)\end{array}$ & 3.76 & .996 & High \\
\hline 3 & $\begin{array}{l}\text { I can identify the characteristics } \\
\text { of the object in the image } \\
\text { displayed through the Tik Tok } \\
\text { video }\end{array}$ & $\begin{array}{l}15 \\
(17.6 \%)\end{array}$ & $\begin{array}{l}41 \\
(48.2 \%)\end{array}$ & $\begin{array}{l}21 \\
(24.7 \%)\end{array}$ & $\begin{array}{l}6 \\
(7.1 \%)\end{array}$ & $\begin{array}{l}2 \\
(2.4 \%)\end{array}$ & 3.72 & .921 & High \\
\hline 4 & $\begin{array}{l}\text { I was able to understand the } \\
\text { object description from the Tik } \\
\text { Tok video that was displayed by } \\
\text { the teacher }\end{array}$ & $\begin{array}{l}18 \\
(21.2 \%)\end{array}$ & $\begin{array}{l}47 \\
(55.3 \%)\end{array}$ & $\begin{array}{l}15 \\
(17.6 \%)\end{array}$ & $\begin{array}{l}2 \\
(2.4 \%)\end{array}$ & $\begin{array}{l}3 \\
(3.5 \%)\end{array}$ & 3.88 & .892 & High \\
\hline 5 & $\begin{array}{l}\text { The use of Tik } \\
\begin{array}{l}\text { Tok videos } \\
\text { improves my ability to } \\
\text { understand and } \\
\text { object }\end{array}\end{array}$ & $\begin{array}{l}23 \\
(27.1 \%)\end{array}$ & $\begin{array}{l}29 \\
(34.1 \%)\end{array}$ & $\begin{array}{l}23 \\
(27.1 \%)\end{array}$ & $\begin{array}{l}7 \\
(8.2 \%)\end{array}$ & $\begin{array}{l}3 \\
(3.5 \%)\end{array}$ & 3.73 & 1.062 & High \\
\hline 6 & $\begin{array}{l}\text { By watching the Tik Tok video, I } \\
\text { became interested in learning to } \\
\text { write text descriptive }\end{array}$ & $\begin{array}{l}11 \\
(12.9 \%)\end{array}$ & $\begin{array}{l}32 \\
(37.6 \%)\end{array}$ & $\begin{array}{l}32 \\
(37.6 \%)\end{array}$ & $\begin{array}{l}9 \\
(10.6 \%)\end{array}$ & $\begin{array}{l}1 \\
(1.2 \%)\end{array}$ & 3.51 & .895 & High \\
\hline
\end{tabular}


Students' perception toward the use of tiktok video in learning writing descriptive text at MAN 1 Gresik

\begin{tabular}{|c|c|c|c|c|c|c|c|c|c|}
\hline 7 & $\begin{array}{l}\text { I am motivated to learn to write } \\
\text { descriptive text if you see the Tik } \\
\text { Tok video }\end{array}$ & $\begin{array}{l}11 \\
(12.9 \%)\end{array}$ & $\begin{array}{l}33 \\
(38.8 \%)\end{array}$ & $\begin{array}{l}30 \\
(35.3 \%)\end{array}$ & $\begin{array}{l}11 \\
(12.9 \%)\end{array}$ & $\begin{array}{l}0 \\
(0 \%)\end{array}$ & 3.52 & .881 & High \\
\hline 8 & $\begin{array}{l}\text { By viewing the Tik Tok video, } \\
\text { process learning becomes more } \\
\text { contextual (relates to or } \\
\text { corresponds to circumstances) }\end{array}$ & $\begin{array}{l}19 \\
(22.4 \%)\end{array}$ & $\begin{array}{l}37 \\
(43.5 \%)\end{array}$ & $\begin{array}{l}24 \\
(28.2 \%)\end{array}$ & $\begin{array}{l}4 \\
(4.7 \%)\end{array}$ & $\begin{array}{l}1 \\
(1.2 \%)\end{array}$ & 3.82 & .880 & High \\
\hline 9 & $\begin{array}{l}\text { Tik Tok videos are stimulating or } \\
\text { stimulating my imagination in } \\
\text { describing an object. }\end{array}$ & $\begin{array}{l}19 \\
(22.4 \%)\end{array}$ & $\begin{array}{l}41 \\
(48.2 \%)\end{array}$ & $\begin{array}{l}18 \\
(21.2 \%)\end{array}$ & $\begin{array}{l}6 \\
(7.1 \%)\end{array}$ & $\begin{array}{l}1 \\
(1.2 \%)\end{array}$ & 3.84 & .898 & High \\
\hline 10 & $\begin{array}{l}\text { The use of the Tik Tok video } \\
\text { encouraged me to participate in } \\
\text { learning write descriptive text }\end{array}$ & $\begin{array}{l}14 \\
(16.5 \%)\end{array}$ & $\begin{array}{l}36 \\
(42.4 \%)\end{array}$ & $\begin{array}{l}30 \\
(35.3 \%)\end{array}$ & $\begin{array}{l}5 \\
(5.9 \%)\end{array}$ & $\begin{array}{l}0 \\
(0 \%)\end{array}$ & 3.69 & .817 & High \\
\hline 11 & $\begin{array}{l}\text { Learn to write descriptive text } \\
\text { with seeing the Tik Tok video } \\
\text { has an appeal alone }\end{array}$ & $\begin{array}{l}20 \\
(23.5 \%)\end{array}$ & $\begin{array}{l}39 \\
(45.9 \%)\end{array}$ & $\begin{array}{l}19 \\
(22.4 \%)\end{array}$ & $\begin{array}{l}6 \\
(7.1 \%)\end{array}$ & $\begin{array}{l}1 \\
(1.2 \%)\end{array}$ & 3.84 & .911 & High \\
\hline 12 & $\begin{array}{l}\text { By watching the Tik Tok video, } \\
\text { learning activities writing } \\
\text { descriptive text becomes more } \\
\text { meaningful and valuable }\end{array}$ & $\begin{array}{l}14 \\
(16.5 \%)\end{array}$ & $\begin{array}{l}34 \\
(40.0 \%)\end{array}$ & $\begin{array}{l}32 \\
(37.6 \%)\end{array}$ & $\begin{array}{l}4 \\
(4.7 \%)\end{array}$ & $\begin{array}{l}1 \\
(1.2 \%)\end{array}$ & 3.66 & .853 & High \\
\hline 13 & $\begin{array}{l}\text { By watching the Tik Tok video, I } \\
\text { became happy and comfortable } \\
\text { learning to write text descriptive }\end{array}$ & $\begin{array}{l}21 \\
(24.7 \%)\end{array}$ & $\begin{array}{l}28 \\
(32.9 \%)\end{array}$ & $\begin{array}{l}27 \\
(31.8 \%)\end{array}$ & $\begin{array}{l}7 \\
(8.2 \%)\end{array}$ & $\begin{array}{l}2 \\
(2.4 \%)\end{array}$ & 3.69 & 1.012 & High \\
\hline 14 & $\begin{array}{l}\text { The use of the Tik Tok video } \\
\text { gave me progress or } \\
\text { improvement in learning write } \\
\text { descriptive text }\end{array}$ & $\begin{array}{l}10 \\
(11.8 \%)\end{array}$ & $\begin{array}{l}37 \\
(43.5 \%)\end{array}$ & $\begin{array}{l}27 \\
(31.8 \%)\end{array}$ & $\begin{array}{l}10 \\
(11.8 \%)\end{array}$ & $\begin{array}{l}1 \\
(1.2 \%)\end{array}$ & 3.53 & .894 & High \\
\hline 15 & $\begin{array}{l}\text { By watching the Tik Tok video I } \\
\text { learned write descriptive text } \\
\text { effectively and efficient }\end{array}$ & $\begin{array}{l}16 \\
(18.8 \%)\end{array}$ & $\begin{array}{l}30 \\
(35.3 \%)\end{array}$ & $\begin{array}{l}28 \\
(32.9 \%)\end{array}$ & $\begin{array}{l}10 \\
(11.8 \%)\end{array}$ & $\begin{array}{l}1 \\
(1.2 \%)\end{array}$ & 3.59 & .967 & High \\
\hline
\end{tabular}

Based on the findings above shows that most of the students' perception toward the use of TikTok video in learning writing descriptive text is positive. As we can see from the questionnaire that have been collected from the students, the result is high. Furthermore, the researcher also found that most of the students agree that the use of TikTok video gives positive contribution in teaching and learning process especially learning writing descriptive text.

There are many positive roles of video in the teaching process especially TikTok video such as help students to understand the content of the video. According to Sherin (2017) Today's video is used to explain and analyze, yet we agree that using video to enable video support is a more effective solution the willingness of teachers to notice and perceive experiences in the classroom. In the other words, TikTok video can help the students understanding the descriptive text through video that have shown in TikTok. It is line with the fouth statement in the questionnaire which is "I was able to understand the object description from the Tik Tok video that was displayed by the teacher". This statement gets positive perception from the learners with the 3.88 mean score and .892 of standard deviation, it means that this statement positive in high level.

In addition, the fifth statement in the questionnaire which is "the use of Tik Tok videos improve my ability to understand and describe an object". This statement get positive in high level perception from the learners with the 3.73 mean score and 1.062 of standard deviation, It means learners agree that TikTok video gives them motivation in learning writing descriptive text. In line with this, commonwealth of learning's website stated that video presents many pedagogical possibilities, including: the provision of practical interactions, the power of inspiration, the opportunity to monitor and review and the participation of students as creators.

Tiktok video are used as a medium in teaching and learning process especially in writing. According to Harmer (2007), music and pictures are very good stimuli for writing and speaking. It is supported by the ninth statement of the questionnaire where Tik Tok videos are stimulating or stimulating students' imagination in describing an object. This statement gets positive perception from 
the studens. The mean score of this statement is 3.84 with .898 of standard deviation. Tiktok Videos are enriched of variety activities which are possibly designed to make the students write as they want in an engaging way. It is in line with the tenth statement of the questionnaire where The use of the Tik Tok video encouraged students to participate in learning write descriptive text. It gets positive perception from them with the number of mean score 3.69 and .817 of standard deviation. In other words, it is in high level.

Furthermore, Wright (1989) notes that one of the conditions for using photographs is that they should be easy to plan and arrange. If it takes a long time for the photographs to be prepared or are difficult to arrange in the classroom, then it will be questioned whether it will be effective and efficient or not. Based on the result of this study, it is found that Tiktok are easy to prepare and organize. It is supported by the fifteenth statement of the questionnaire whereby watching the Tik Tok video, the students learned write descriptive text effectively and efficient. It gets positive perception from them. This statement is in very high level with 3.59 of mean score and .967 of standard deviation.

Based on the result of this study, it is found that the use of Tiktok grows the student's interest in learning writing descriptive text. Wright (1989) states that one of the criteria in using pictures is they should be interesting and attractive for the students. If the activity is considered unlikely to interest the students, then it will be questioned whether it is worth doing or not. It is supported by sixth and eleventh statement in the questionnaire. The sixth statement states that by watching the Tik Tok video, Students became interested to learn writing text descriptive. It gets positive perception with 3.51of mean score, .895 of standard deviation, and it is in high level. Beside that, the eleventh statement states that students motivated to learn writing descriptive text if they see the Tik Tok video. It gets positive perception with the number of mean score 3.52 and standard deviation .881 It indicates that it is in very high level. It means that the'Tiktok Video which are used by students in learning writing descriptive text fill one of the criteria.

The other criteria in using tiktok that is explained by Wright (1989) is they should be meaningful and authentic. What students learn at this stage should be enough for the real context or circumstance in which they use the language with native speakers and should reflect on the meaning as well. Based on the result of this study, it is found that the use of Tiktok makes the learning of writing descriptive text become meaningful and valuable for the students. The fifteen declaration in the questionnaire confirms it. The twelfth assertion notes that by watching the Tik Tok video, learning activities writing descriptive text becomes more meaningful and valuable. It gets positive perception with the number of mean score 3.66 and standard deviation .853. It is also in very high level. Beside that, most of students agree that they feel happy and comfortable in learning writing descriptive text by watching Tiktok Video. The result of this study indicates that Tiktok Video are effective to be applied as media in learning writing descriptive text since they get positive perception from the students. It is indicated by the average level of mean scores which is very high. This study shares the same result as what have been investigated by some previous research such as Fitriani (2008). Based on the result, the teaching writing through pictures was successful to improve students' descriptive writing skill. In the other words, pictures are effective as media in improving descriptive writing skill. Moreover,

The result of this study is also similar with the other study done by Sari (2014). The findings revealed that the teaching writing through TikTok was successful to improve students' descriptive writing skill. Specifically, they showed some improvement on schematic structure, grammar roles, and graphic features.

\section{CONCLUSIONS}

Results of the research indicates that perception of the students toward the use of Tik Tok in learning writing descriptive text is positive. Students have positive response about it. fifteen questionnaire items were in high level. There was no questionnaire item in medium, low, or very low level. It means that the use of Tik Tok give benefits and positive effect for the students in learning writing descriptive text. 
The use of Tik Tok contributes positively to learning writing descriptive text. The photos add to the context where the language is used. Pictures put the world into the classroom, in other words. The use of Tik Tok in learning process can grow the motivation and make the students pay attention and engage. Tik Tok are enriched of variety activities which are possibly designed to make the students write as they want in an engaging way. To create the effective and efficient learning process, there are some criteria in using Tik Tok that should be seriously considered.

The suggestion of the research are students in this study have positive perception toward the use of Tik Tok in learning writing descriptive text. Many students agree that the use of Tik Tok in learning writing descriptive text give benefits and positive effect in their learning. It can be an alternative for the other teachers to use Tik Tok for teaching the students in order to create a contextual, meaningful, and attractive learning activities and promote the students being engaged in the learning activities. It is suggested for teachers that use or want to use Tik Tok in teaching the students writing descriptive text to concern with the criteria of using Tik Tok such as considering the time in preparing the material, thinking how to organize it, designing it attractively, questioning whether it is meaningful and authentic or not, and so on. If those criteria are fulfilled, the effective learning process will run.

\section{REFERENCES}

Fauziati, E., Ariatmi, S, Z., Laila, M., Srijono, D., Wijayanto, A., Fatmawati, R., et al. (2014). Modul PLPG 2014. Kendari: Universitas Halu Uleo.

Fitriani, S. W. N. (2008). The effectiveness of using pictures in writing descriptive text to the eight grade students of junior high school in the academic year of 2008/2009. Unpublished S1 Thesis. Semarang: Semarang State University.

Harmer, J. (2004). How to teach writing. England: Pearson Education Limited.

Harmer, J. (2007). How to teach English. England: Pearson Education Limited.

Hyland, K. (2003). Second language writing. New York: Cambridge University Press.

Ilmi, I. K. (2014). The use of picture prompts to improve students' writing in descriptive texts. Unpublished S1 Thesis. Semarang: Semarang State University.

Ilmiyah, N. H., Sulistyaningsih., \& Musyarofah, L. (2014). Teaching writing descriptive text by using pictures to the eighth-grade students of SMP Negeri 2 Buduran Sidoarjo. Sidoarjo: LPPM STKIP PGRI Sidoarjo.

Khoii, R. (2011). A solution to the dilemma of writing in a foreign language: Adaptive mentorship. international journal for cross-disciplinary subjects in education (IJCDSE), 2(4). 493-494.

Ministry of Education and Culture. (2014). Konsep dan implementasi kurikulum 2013. Jakarta: Ministry of Education and Culture.

Sari, R. M. (2014). The use of pictures to improve students' ability in writing descriptive texts. Unpublished S1 Thesis. Bandung: Universitas Pendidikan Indonesia.

Wright, A. (1989). Pictures for language learning. Cambridge: Cambridge University Press.

Khoii, R. (2011). A solution to the dilemma of writing in a foreign language: Adaptive mentorship. international journal for cross-disciplinary subjects in education (IJCDSE), 2(4). 493-494

Jeremy Harmer, The Practice of Language Teaching, (Cambridge: Ashford Colour Press, (2007), 177.

Prayitno, Hadi, et.al. (2020). Rancang Bangun Media Pembelajaran Radio Theory I Berbasis Multimedia Animasi. Riset dan E-Jurnal Manajemen Informatika Komputer, 4(2). https://doi.org/10.33395/remik.v4i2.10560

Deriyanto, Demmy, and Qorib, Fathul. (2018). Persepsi Mahasiswa Universitas Tribhuwana Tunggadewi Malang Terhadap Penggunaan Aplikasi Tik Tok. JISIP: Jumal Ilmu Sosial dan Imu Politik. 7(2)

Hiew, A. (2005). Introduxtion to academic writing. New York, NY: Pearson Education Inc.. https://www.col.org/news/col-blog/importance-tiktok-type-videos-learning Accessed 17th October 2020 at 11.40 a.m 